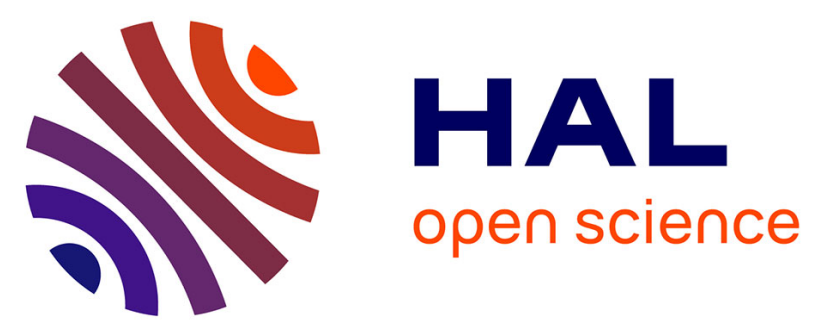

\title{
Establishment of reference values in a healthy population and interpretation of serum PTH concentrations in hemodialyzed patients according to the KDIGO Guidelines using the Lumipulse ${ }^{\circledR}$ G whole PTH (3rd generation) assay
}

Etienne Cavalier, Margot Salsé, Anne-Marie Dupuy, Anne-Sophie Bargnoux, Florence Watar, Jean-Claude Souberbielle, Pierre Delanaye, Jean-Paul Cristol

\section{- To cite this version:}

Etienne Cavalier, Margot Salsé, Anne-Marie Dupuy, Anne-Sophie Bargnoux, Florence Watar, et al.. Establishment of reference values in a healthy population and interpretation of serum PTH concentrations in hemodialyzed patients according to the KDIGO Guidelines using the Lumipulse® G whole PTH (3rd generation) assay. Clinical Biochemistry, 2018, 54, pp.119 - 122. 10.1016/j.clinbiochem.2018.02.019 . hal-01786739

\section{HAL Id: hal-01786739 \\ https://hal.umontpellier.fr/hal-01786739}

Submitted on 7 Jan 2020

HAL is a multi-disciplinary open access archive for the deposit and dissemination of scientific research documents, whether they are published or not. The documents may come from teaching and research institutions in France or abroad, or from public or private research centers.
L'archive ouverte pluridisciplinaire HAL, est destinée au dépôt et à la diffusion de documents scientifiques de niveau recherche, publiés ou non, émanant des établissements d'enseignement et de recherche français ou étrangers, des laboratoires publics ou privés. 


\title{
Establishment of reference values in a healthy population and interpretation of serum PTH concentrations in hemodialyzed patients according to the KDIGO Guidelines using the Lumipulse ${ }^{\circledR} \mathrm{G}$ whole PTH (3rd generation)
}

\author{
assay \\ Etienne Cavalier ${ }^{\mathrm{a}, *}$, Margot Salsé ${ }^{\mathrm{b}}$, Anne-Marie Dupuy ${ }^{\mathrm{b}}$, Anne-Sophie Bargnoux ${ }^{\mathrm{b}}$, \\ Florence Watar $^{\mathrm{a}}$, Jean-Claude Souberbielle ${ }^{\mathrm{c}}$, Pierre Delanaye ${ }^{\mathrm{d}}$, Jean-Paul Cristol ${ }^{\mathrm{b}}$ \\ a Department of Clinical Chemistry, University of Liège, CHU de Liège, Belgium \\ ${ }^{\mathrm{b}}$ Department of Biochemistry and Hormonology, Lapeyronie Hospital, Montpellier, France \\ ${ }^{\mathrm{c}}$ Service des Explorations Fonctionnelles, Hôpital Necker-Enfants Malades, Paris, France \\ ${ }^{\mathrm{d}}$ Department of Nephrology, Dialysis and Transplantation, University of Liège, CHU de Liège, Belgium
}

Keywords:

Parathyroid hormone

PTH

Reference value

KDIGO

\section{A B S T R A C T}

Background: 3rd generation PTH assays only detect the bioactive 1-84 fragment. Since standardization is still lacking, each new PTH assay requires to establish reference values and to assess the impact in the medical care of the mineral and bone disorders in hemodialyzed patients.

Methods: Using Fujirebio Lumipulse G wPTH assay, serum PTH levels were measured in a population of 439 healthy subjects from France and Belgium PTH levels were also determined in 119 hemodialyzed patients. These patients were classified according to the KDIGO recommendation.

Results: Reference range was found to be 6.5 (90\%CI: 6.0-7.0) - 41.8 (90\% CI: 38.1-43.7). In hemodialysis patients, Passing-Bablock regression between 3rd generation PTH from Fujirebio and DiaSorin was DiaSorin $=1.01$ xFujirebio-2.4 with a slope not different from 1.0(95\%CI: 0.96-1.04) and a non-significant intercept, ranging from -6.0 to 0.1 . Hemodialysis patients with a PTH concentration below 2-fold the Upper Limit of Normality (ULN), within the KDIGO range and upper 9-fold upper limit were respectively 33.6\%, 54.6\%, 11.8\% (Fujirebio Lumipulse) and 36.1\%, 51.3\% and 12.6\% (Diasorin Liaison).

Conclusion: We determined a reference range with the 3rd generation PTH assay from Fujirebio. In a hemodialysis population, 3rd generation assays from Fujirebio and DiaSorin provide similar results. To the best of our knowledge, this is the first time that we can show similar PTH results obtained by 2 different 3rd generation PTH assays in healthy subjects and hemodialyzed patients without mathematically processing them.

\section{Introduction}

Serum parathyroid hormone (PTH) is frequently measured in clinical practice. Indeed, assessment of PTH concentration is of paramount importance in the exploration of disorders of calcium/phosphorus metabolism and in the monitoring of patients suffering from chronic kidney disease (CKD). Unfortunately, PTH measurement and clinical interpretation of the results is not an easy task. From an analytical point of view, different generations of PTH assays are present on the market. The older ones, called "intact" PTH or 2nd generation PTH assays are known to cross-react with N-terminal truncated PTH fragments, generally called (7-84) PTH or non-(1-84) PTH that are suspected to increase in CKD [1]. The more recent ones are called 3rd generation assays and do not detect the non-(1-84) PTH but measure however a post-translational form called amino-PTH, that is overproduced in many patients suffering from parathyroid carcinomas [2]. Standardization of these assays is still lacking and we are still waiting for a reference method for PTH determination, as well as commutable calibrators, even if an International Standard, namely the WHO 95/646, is available [3]. In practice, results obtained with the 2nd or 3rd generation assays are not transposable, especially for CKD patients, which is most confusing for clinicians [4]. We have however recently shown that standardization of 3rd generation PTH assays from DiaSorin and Roche with the WHO 95/646 Standard could reduce significantly inter-

\footnotetext{
* Corresponding author at: Department of Clinical Chemistry, University of Liège, CHU Sart-Tilman, B-4000 Liège, Belgium.

E-mail address: Etienne.cavalier@chu.ulg.ac.be (E. Cavalier).
} 
method variability [5].

From a clinical perspective, the Guidelines for the diagnosis and management of asymptomatic primary hyperparathyroidism (GDMAPHP) [6] as well as the KDIGO Guidelines [7], emphasize that 2nd and 3rd generation PTH assays have similar clinical values for the diagnosis of primary hyperparathyroidism and for the follow-up of CKD-related mineral and bone disorders (CKD-MBD). Hence, a correct establishment of PTH reference ranges is of particular interest to rapidly detect a secondary hyperparathyroidism and to properly classify hemodialyzed patients according to multiples of the Upper Limit of Normal (ULN), as recommended by the KDIGO [7-9].

In this context, Fujirebio (Tokyo, Japan) has recently launched a new 3rd generation PTH assay on the Lumipulse platform. The aim of this study was to determine PTH reference values for this new automated method in a French (Montpellier) and Belgian (Liege) vitamin D replete populations. We also classified dialysis patients according to KDIGO Guidelines (which recommends maintaining the hemodialysis (HD) patients at 2-9 times the ULN) with the Fujirebio and DiaSorin 3rd generation PTH assays.

\section{Material and methods}

\subsection{Patients}

We selected a reference population of 269 healthy subjects from Montpellier (France) and 184 healthy subjects from Liège (Belgium) that presented normal calcium and phosphorus levels, eGFR $>60 \mathrm{~mL} /$ $\mathrm{min} / 1.73 \mathrm{~m}^{2}$ and $25(\mathrm{OH})$-vitamin $\mathrm{D}(25(\mathrm{OH}) \mathrm{D})$ levels $>30 \mathrm{ng} / \mathrm{mL}$ as recommended [6] to establish PTH reference range. We also selected a population of 119 hemodialyzed patients from CHU Lapeyronie (Montpellier) undergoing dialysis three times a week. Blood was obtained just before a dialysis session and was centrifuged within $30 \mathrm{~min}$ of blood sampling. Serum was aliquoted and stored at $-80^{\circ} \mathrm{C}$ until assayed.

\subsection{PTH assays}

The Lumipulse G whole PTH (3rd generation) assay is a chemiluminescent sandwich method using a pair of polyclonal goat anti-PTH antibodies, one targeted against the C-terminal and the other against the first amino-acids of the peptide. The coefficient of variation (CV) of the method ranges from 1.4 to $6.9 \%$, the limit of detection (LOD) is $0.6 \mathrm{pg} / \mathrm{mL}$ and the limit of quantification (LOQ) is $4.0 \mathrm{pg} / \mathrm{mL}$. Expected range on serum (p2.5-p97.5) established by Fujirebio on 133 apparently healthy white Europeans presenting 25(OHD) values $>30 \mathrm{ng} / \mathrm{mL}$, eGFR $>60 \mathrm{~mL} / \mathrm{min} / 1.73 \mathrm{~m}^{2}$ and normal calcium and phosphorus levels is $5.5-31.9 \mathrm{pg} / \mathrm{mL}$. The method is claimed to be traceable to the NIBSC WHO 95/646 recombinant, human, 1-84 PTH Standard (1st International Standard).

The Liaison (1-84) PTH immunoassay (3rd generation) (DiaSorin, Stillwater, MN,USA) is a two-step automated sandwich chemiluminescent immunoassay that also uses two polyclonal antibodies targeted against the C-terminal and the first amino acids of the peptide. The CV of the method is $5.5 \%, 4.1 \%, 4.0 \%$ and $4.7 \%$ at $10.6,33.5,378$ and $1662 \mathrm{pg} / \mathrm{mL}$, respectively. The LOD is $1.7 \mathrm{pg} / \mathrm{mL}$ and the LOQ is $4.0 \mathrm{pg} /$ $\mathrm{mL}$. The expected range established on serum by DiaSorin using 74 apparently healthy adults from the Midwest of the USA presenting $25(\mathrm{OH}) \mathrm{D}$ values $>30 \mathrm{ng} / \mathrm{mL}$ and normal calcium and phosphorus levels is $5.5-38.4 \mathrm{pg} / \mathrm{mL}$. The ULN, however, has been challenged in white European populations and found to be (p97.5) at $28.8 \mathrm{pg} / \mathrm{mL}$ [9] and $28.9 \mathrm{pg} / \mathrm{mL}$ [8]. The method has been calibrated against an internal, synthetic human 1.84 PTH without any other specification.

\subsection{Statistics}

Non-parametric statistics were used when distribution was not
Gaussian according to the D'Agostino-Pearson test and results were expressed as median (95\% confidence interval). We used Medcalc (Oostende, Belgium) to calculate the Mann-Whitney tests and the the lower and upper limits of normality were calculated as the p2.5 and p97.5 of the distribution by the non-parametric percentile method, according to the CLSI C28-A3 Guideline. Agreement between classification of the hemodialyzed patients was assessed with the kappa test. A $\mathrm{p}$ value $<0.05$ was considered as significant.

\section{Results}

\subsection{Healthy population}

The reference population in Montpellier consisted in 136 healthy men and 133 healthy women, with a median age of 43 years (95\% CI: $39-46.0$ ) ranging from 18 to 89 years old. The median 25(OH)D value was 41 (95\%CI: 40.0-43.0; range: $30-100) \mathrm{ng} / \mathrm{mL}$. No gender related difference was observed for age or $25(\mathrm{OH}) \mathrm{D}$ values.

The median Fujirebio Lumipulse 3rd generation PTH value in these 269 subjects was $16.3 \mathrm{pg} / \mathrm{mL}$ (Q1: $12.0 \mathrm{pg} / \mathrm{mL}$; Q3: $23.5 \mathrm{pg} / \mathrm{mL}$; and IQR: $11.5 \mathrm{pg} / \mathrm{mL}$ ). The upper and lower limits of normality of PTH values (2.5th-97.5th percentile) were 6.1 (90\%CI: 5.6; 6.8) - 41.6 (36.9; 44.7) $\mathrm{pg} / \mathrm{mL}$ according to the CLSI C28-A3 Guideline. No gender related difference was observed.

In Liege, the reference population consisted in 58 healthy men and 126 healthy women, with a median age of 58.5 (95\% CI: 56.0-61) years ranging from 18 to 94 years. The median 25(OH)D value was 35.9 (90\%CI: 34.1-37.2; range: 30-59.8) ng/mL. Like in Montpellier, there was no significant difference between age and $25(\mathrm{OH}) \mathrm{D}$ values in males vs. females.

The median PTH value in these 184 subjects was $19.1 \mathrm{pg} / \mathrm{mL}(\mathrm{Q} 1$ : $14.7 \mathrm{pg} / \mathrm{mL}$; $\mathrm{Q}$ : $23.6 \mathrm{pg} / \mathrm{mL}$; and IQR: $8.9 \mathrm{pg} / \mathrm{mL}$ ). The upper and lower limits of normality of PTH values (2.5th-97.5th percentile) were 8.8 (90\%CI: $4.4 ; 9.5)-42.7(35.2 ; 47.5) \mathrm{pg} / \mathrm{mL}$ according to the CLSI C28-A3 Guideline. No gender related difference was observed.

Altogether, the Fujirebio Lumipulse 3rd generation PTH reference range, established in 453 Individuals according to the non-parametric percentile method, was found to be 6.5 (90\%CI: 6.0-7.0) - 41.8 (90\% CI: $38.1-43.7) \mathrm{pg} / \mathrm{mL}$.

The subjects from Liege were older $(\mathrm{p}<0.0001)$ and presented lower 25(OH)D $(\mathrm{p}<0.0001)$ and higher PTH $(\mathrm{p}=0.0045)$ values compared to those from Montpellier. In simple regression analysis, serum PTH levels in the whole group of 439 subjects correlated positively with age $(r=0.28$; $p<0.001)$ but not with serum 25(OH)D. The median PTH concentration in subjects $<60$ years old $(n=306)$ was $16.5 \mathrm{pg} / \mathrm{mL}$ (2.5th-97.5th percentile: $6.2-32.4 \mathrm{pg} / \mathrm{mL}$ ), a value significantly lower than in subjects aged 60 years or more $(n=133)$ who had a median PTH concentration of $19.0 \mathrm{pg} / \mathrm{mL}(\mathrm{p}<.001)$. This had however little impact on the reference range since it was calculated at $6.2-33.0$ in older vs. $6.3-34.7 \mathrm{pg} / \mathrm{mL}$ in younger individuals.

\subsection{Hemodialyzed patients}

The main characteristics of the 129 patients are summarized in Table 1.

PTH (either Fujirebio or DiaSorin) was significantly correlated with Calcium ( $\mathrm{r}=-0.19 ; \mathrm{p}<0.05)$, age $(\mathrm{r}=0.188$; $\mathrm{p}<0.05)$ and bone alkaline phosphatase $(r=0.478 ; p<0.0001)$ but not with $25(\mathrm{OH}) \mathrm{D}$ or phosphorus. In multiple regression, PTH only remained associated with bone alkaline phosphatase.

According to the KDIGO, the interval encompassing 2 to 9 times the ULN determined in the present study will be $84-378 \mathrm{pg} / \mathrm{mL}$ for the Fujirebio whole PTH assay. For the DiaSorin assay, it will be $76-342 \mathrm{pg} / \mathrm{mL}$ according to DiaSorin reference range or $58-260 \mathrm{pg} / \mathrm{mL}$ according to Souberbielle et al. [8] and Cavalier et al. [9]. The classification of patients is presented in Table 2. Compared to Fujirebio, the 


\section{Acknowledgements}

Fujirebio kindly provided the Lumipulse reagents for the study.

\section{References}

[1] P. D'Amour, J.H. Brossard, A. Räkel, et al., Evidence that the amino-terminal composition of non-(1-84) parathyroid hormone fragments starts before position 19, Clin. Chem. 51 (2005) 169-176, http://dx.doi.org/10.1373/clinchem.2004. 040485.

[2] E. Cavalier, A.F. Daly, D. Betea, et al., The ratio of parathyroid hormone as measured by third- and second-generation assays as a marker for parathyroid carcinoma, J. Clin. Endocrinol. Metab. 95 (2010) 3745-3749, http://dx.doi.org/10 1210/jc. 2009-2791.

3] E. Cavalier, P. Delanaye, L. Nyssen, J.-C.C. Souberbielle, Problems with the PTH assays, Ann. Endocrinol. (Paris) 76 (2015) 128-133, http://dx.doi.org/10.1016/j. ando.2015.03.018.

[4] J.-C. Souberbielle, Carlier M.-C. Boutten a, et al., Inter-method variability in PTH measurement: implication for the care of CKD patients, Kidney Int. 70 (2006) 345-350, http://dx.doi.org/10.1038/sj.ki.5001606.

[5] E. Cavalier, P. Delanaye, P. Lukas, et al., Standardization of DiaSorin and Roche automated third generation PTH assays with an International Standard: impact on clinical populations, Clin. Chem. Lab. Med. 52 (2014) 7-11, http://dx.doi.org/10. 1515/cclm-2013-1027.

[6] J.P. Bilezikian, M.L. Brandi, R. Eastell, et al., Guidelines for the Management of Asymptomatic Primary Hyperparathyroidism: summary statement from the fourth international workshop, J. Clin. Endocrinol. Metab. 99 (2014) 3561-3569, http:// dx.doi.org/10.1210/jc.2014-1413.

[7] S.M. Moe, T.B. Drueke, Group for the KW, KDIGO clinical practice guideline for the diagnosis, evaluation, prevention and treatment of chronic kidney disease mineral and bone disorder (CKD-MBD), Kidney Int. 76 (2009) S1-S128, http://dx.doi.org/ 10.1038/ki.2009.188.

[8] J.-C.C. Souberbielle, C. Massart, S. Brailly-Tabard, et al., Serum PTH reference values established by an automated third-generation assay in vitamin D-replete subjects with normal renal function: consequences of diagnosing primary hyperparathyroidism and the classification of dialysis patients, Eur. J. Endocrinol. 174 (2016) 315-323, http://dx.doi.org/10.1530/EJE-15-0595.

[9] E. Cavalier, P. Delanaye, L. Vranken, et al., Interpretation of serum PTH concentrations with different kits in dialysis patients according to the KDIGO guidelines: importance of the reference (normal) values, Nephrol. Dial. Transplant. 27 (2011) 1950-1956, http://dx.doi.org/10.1093/ndt/gfr535.

[10] E. Cavalier, P. Delanaye, Defining a "reference population": no easy task, J. Bone Miner. Res. 24 (2009) 1638, http://dx.doi.org/10.1359/jbmr.090322.

[11] M. Touvier, M. Deschasaux, M. Montourcy, et al., Interpretation of plasma PTH concentrations according to 25OHD status, gender, age, weight status, and calcium intake: importance of the reference values, J. Clin. Endocrinol. Metab. 99 (2014) 1196-1203, http://dx.doi.org/10.1210/jc.2013-3349.

[12] E. Cavalier, J.C. Souberbielle, Establishment of parathyroid hormone (PTH) reference range on 10 different assay kits: impact of the recruitment of the population, Osteoporos. Int. 23 (2012) S360.

[13] J.-C. Souberbielle, F. Brazier, M.-L. Piketty, et al., How the reference values for serum parathyroid hormone concentration are (or should be) established? J. Endocrinal. Investig. 40 (2016) 241-256.

[14] S.L. La'ulu, W.L. Roberts, Performance characteristics of six intact parathyroid hormone assays, Am. J. Clin. Pathol. 134 (2010) 930-938, http://dx.doi.org/10. 1309/AJCPLGCZR7IPVHA7.

[15] L. Rejnmark, P. Vestergaard, L. Heickendorff, L. Mosekilde, Determinants of plasma PTH and their implication for defining a reference interval, Clin. Endocrinol. 74 (2011) 37-43, http://dx.doi.org/10.1111/j.1365-2265.2010.03894.x.

[16] J.-C.P. Souberbielle, H. Roth, D.P. Fouque, Parathyroid hormone measurement in CKD, Kidney Int. 77 (2010) 93-100, http://dx.doi.org/10.1038/ki.2009.374. 